\title{
Nutrition profile of a liver transplant recipient
}

\author{
Neha Bakshi, Kalyani Singh
}

Department of Foods and Nutrition, Lady Irwin College, University of Delhi, New Delhi 110001, India.

\begin{abstract}
Malnutrition is almost universally present in patients undergoing liver transplantation. In this report, a male adult patient was followed from his pre-liver transplant phase until chronic post-transplant phase ( 3 months after the transplant). Improvement in nutrition status, quality of life, and performance status was seen from the pre-transplant to chronic post-transplant phase. Day to day nutrition monitoring and gradual increase in calorie and protein intake was seen in the acute post-transplant phase, but during pre- and chronic post-transplant phase, lack of nutrition support was observed in the patient.

Key words: Liver transplant; malnutrition; nutrition profile
\end{abstract}

\section{Address for correspondence:}

Ms. Neha Bakshi, Department of Foods and Nutrition, Lady Irwin College, University of Delhi, Sikandra Road, Mandi House, New Delhi 110001, India. E-mail: nehabakshi.9@gmail.com

Received: 21-06-2015, Accepted: 19-10-2015

\section{INTRODUCTION}

Liver transplantation (LT) is the only treatment for the end-stage liver disease (ESLD). ${ }^{[1]}$ It is estimated that malnutrition occurs in $65-100 \%$ of patients with ESLD. ${ }^{[2,3]}$ Medical nutrition therapy provided by a registered dietician is necessary during all phases of LT for improved surgical outcomes. ${ }^{[4]}$

\section{CASE REPORT}

Nutrition therapy for LT is divided into three phases: (1) pre-transplant - provision of adequate nutrients without aggravating ESLD symptoms; (2) acute posttransplant - high protein feeds through various routes to achieve adequate intakes; and (3) chronic posttransplant - aggressive nutrition therapy for improved survival. ${ }^{[4]}$

\section{Pre-transplant phase}

A 54-year-old Indian male patient diagnosed with

\begin{tabular}{|l|c|}
\hline \multicolumn{3}{|c|}{ Access this article online } \\
\hline \multirow{2}{*}{ Website: } & Quick Response Code \\
http://hrjournal.net & \\
\hline &
\end{tabular}

ethanol and hepatitis $\mathrm{C}$ virus-related chronic liver disease underwent living donor LT (Child-Turcotte-Pugh score $^{[5]}=8$, Model for ESLD score ${ }^{[6]}=14$ ). Medical history showed the patient suffered from jaundice (for 2 years), ascites (for 3 months) and excessive fatigue (for 15 days). The patient was admitted 12 days before LT. Biochemical parameters before LT depicted deranged results [Table 1].

Nutrition status assessment by anthropometry depicted mild malnutrition by mid-arm muscle circumference (MAMC) and severe malnutrition by triceps measurement. ${ }^{[7]}$ Subjective global assessment (SGA) showed moderate malnutrition. ${ }^{[8]}$ Hand grip strength (both hands) showed severe malnutrition. ${ }^{|9|}$

Body composition analysis depicted standard physique of the patient with normal levels of fat percentage, fatfree mass (FFM), and muscle mass [Table 2]. ${ }^{[10]}$

This is an open access article distributed under the terms of the Creative Commons Attribution-NonCommercial-ShareAlike 3.0 License, which allows others to remix, tweak, and build upon the work non-commercially, as long as the author is credited and the new creations are licensed under the identical terms.

For reprints contact: service@oaepublish.com

How to cite this article: Bakshi N, Singh K. Nutrition profile of a liver transplant recipient. Hepatoma Res 2016;2:98-102. 
Diet history depicted no gastrointestinal (GI) symptoms, dental or oral problem, or food allergies. The simplified nutritional appetite questionnaire (SNAQ) score was 16 hence there was no significant risk of at least $5 \%$ weight loss within 6 months. ${ }^{[1]}$ The patient was alcoholic (CAGE score > 2). ${ }^{[12]}$ He was recommended an oral normal diet with supplements providing $2700 \mathrm{kcal}, 115 \mathrm{~g}$ of proteins with salt $(2 \mathrm{~g})$ and fluid restriction $(1.5 \mathrm{~L} /$ day $){ }^{[4]}$ Patients' intake was $1100 \mathrm{kcal}$ and $40 \mathrm{~g}$ protein, indicating consumption of $57.6 \%$ of the recommended calories.

Table 1: Biochemical parameters of the patient before the transplant

\begin{tabular}{|c|c|c|c|c|c|}
\hline $\begin{array}{l}\text { Biochemical } \\
\text { parameter }\end{array}$ & Value & Range & $\begin{array}{l}\text { Biochemical } \\
\text { parameter }\end{array}$ & Value & Range \\
\hline $\mathrm{Hb}(\mathrm{mg} / \mathrm{dL})$ & 8.5 & $13-7$ & $\mathrm{Na}(\mathrm{mmol} / \mathrm{L})$ & 134 & $137-145$ \\
\hline WBC ( $\left.10^{3} / \mathrm{UL}\right)$ & 8.31 & $4.00-10.00$ & $\mathrm{~K}(\mathrm{mmol} / \mathrm{L})$ & 3.7 & $3.5-5.1$ \\
\hline $\begin{array}{l}\text { Platelets } \\
\left.\text { (10 } / 0^{3} / \mathrm{LL}\right)\end{array}$ & 100 & $150-410$ & $\mathrm{Ca}(\mathrm{mg} / \mathrm{dL})$ & 8.9 & $8.4-10.2$ \\
\hline Alb (g/L) & 3 & $3.5-5.0$ & $\mathrm{Mg}(\mathrm{mg} / \mathrm{dL})$ & 1.5 & $1.6-2.3$ \\
\hline $\begin{array}{l}\text { Bili (D) } \\
\text { (mg/dL) }\end{array}$ & 0.1 & $0.2-1.3$ & $\mathrm{P}(\mathrm{mg} / \mathrm{dL})$ & 4.3 & $2.5-4.5$ \\
\hline $\begin{array}{l}\text { Bili (T) } \\
(\mathrm{mg} / \mathrm{dL})\end{array}$ & 1.5 & $0.2-1.3$ & $\mathrm{Cl}(\mathrm{mmol} / \mathrm{L})$ & 106 & $98-107$ \\
\hline $\begin{array}{l}\text { Total protein } \\
\text { (g/L) }\end{array}$ & 6.4 & 6.38 .2 & PT & 15.6 & $8.8-12.3$ \\
\hline $\begin{array}{l}\text { ALT/SGPT } \\
(\mathrm{U} / \mathrm{L})\end{array}$ & 23 & $21-72$ & INR & 1.51 & \\
\hline $\begin{array}{l}\text { AST/SGOT } \\
\text { (U/L) }\end{array}$ & 34 & 7-51 & $\begin{array}{l}\text { CRprotein } \\
\text { (mg/dL) }\end{array}$ & 11.6 & $0.0-10.0$ \\
\hline $\begin{array}{l}\text { yglutamyl } \\
\text { transferase } \\
\text { (U/L) }\end{array}$ & 28 & $15-73$ & & & \\
\hline $\begin{array}{l}\text { Alkaline } \\
\text { phosphates } \\
\text { (U/L) }\end{array}$ & 63 & $30-120$ & & & \\
\hline Urea (mg/dL) & 61 & $10-50$ & & & \\
\hline $\mathrm{Cr}(\mathrm{mg} / \mathrm{dL})$ & 1.6 & $0.80-1.50$ & & & \\
\hline
\end{tabular}

$\mathrm{Hb}$ : hemoglobin; WBC: white blood cell; Alb: albumin; Bili: bilirubin; ALT: alanine aminotransferase; AST: aspartate aminotransferase; Cr: creatinine; PT: prothrombin time; INR: international normalized ratio; CR protein: C-reactive protein; SGPT: serum glutamic pyruvic transaminase; SGOT: serum glutamic oxaloacetic transaminase

Table 2: Nutrition assessment of the patient

\begin{tabular}{|c|c|c|}
\hline Parameter & Observation & Evaluation \\
\hline \multicolumn{3}{|l|}{ Anthropometric evaluation } \\
\hline Weight (kg) & 73.9 & \multirow{5}{*}{$\begin{array}{l}\text { Severe } \\
\text { malnutrition } \\
\text { Mild malnutrition }\end{array}$} \\
\hline Height $(\mathrm{cm})$ & 176 & \\
\hline Ideal body weight (kg) & 76 & \\
\hline $\operatorname{Triceps}^{[7]}(\mathrm{cm})$ & 0.56 & \\
\hline $\begin{array}{r}\operatorname{MAMC}^{[7]}(\mathrm{cm}) \\
\operatorname{SGA}^{[8]}\end{array}$ & 22 & \\
\hline $\mathrm{SGA}^{[8]}$ & 6 & $\begin{array}{l}\text { Moderate } \\
\text { malnutrition }\end{array}$ \\
\hline \multicolumn{3}{|c|}{$\begin{array}{l}\text { Body composition analysis by } \\
\text { bioelectrical impedance analysis }{ }^{[9]}\end{array}$} \\
\hline Weight $(\mathrm{kg})$ & 72.55 & Normal \\
\hline Fat (\%) & 22.5 & Normal \\
\hline Fat mass & 16.3 & Normal \\
\hline FFM (kg) & 56.25 & Normal \\
\hline Muscle mass (kg) & 53.35 & Normal \\
\hline BMI & 23.2 & Normal \\
\hline
\end{tabular}

Eastern Cooperative Oncology Group (ECOG) performance status score of 3 indicated that the patient was capable of only limited self-care and unable to carry out any work activities that was $\geq 50 \%$ of working hours. ${ }^{[13]}$ Quality of life (QOL) assessment by short form-36 before LT depicted low level in its eight dimensions [Figure 1]. ${ }^{[14]}$

\section{Acute post-transplant phase}

The altered blood parameters are important for implementing the nutrition therapy plan. Deranged biochemical parameters in this phase are presented in Figure 2a-h. The patient had been in intensive care unit for 3 days. At post-operation day (POD), 1 patient was extubated within $24 \mathrm{~h}$ and was provided propofol $45 \mathrm{~mL}(1 \mathrm{kcal} / \mathrm{mL})$ and dextrose normal saline $440 \mathrm{~mL}$ (17 kcal/100 mL), KCl $45 \mathrm{~mL}$ intravenously. On POD 2 propofol, $120 \mathrm{~mL}$ and $\mathrm{KCl} 120 \mathrm{~mL}$ was given. On POD $3 \mathrm{KCl} 40 \mathrm{~mL}$ along with oral liquids ( $250 \mathrm{kcal}$ ) was given. On POD 4, he was transferred to the LT unit and was given oral high protein normal diet with supplements providing 2,700 kcal and $115 \mathrm{~g}$ protein. The patient was not able to complete meals (especially lunch and dinner), because of nausea and lack of appetite. An increasing trend of energy and protein consumption after LT during the hospital stay is indicated in Figure 3. The patient met $76.4 \%$ and $103 \%$ of the recommended calorie and protein intake, respectively. The patient was discharged on POD 15, on 2,700 kcal and $115 \mathrm{~g}$ of proteins (high protein, low potassium normal diet) out of which $375 \mathrm{kcal}$ and $36 \mathrm{~g}$ of protein were from low potassium nutrition supplements and about $352 \mathrm{kcal}$, and $24 \mathrm{~g}$ protein was from high calorie-protein biscuits. ${ }^{[4]}$ He was recommended to take multivitamins and potassium binding medications, to monitor glucose regularly, and to avoid the outer

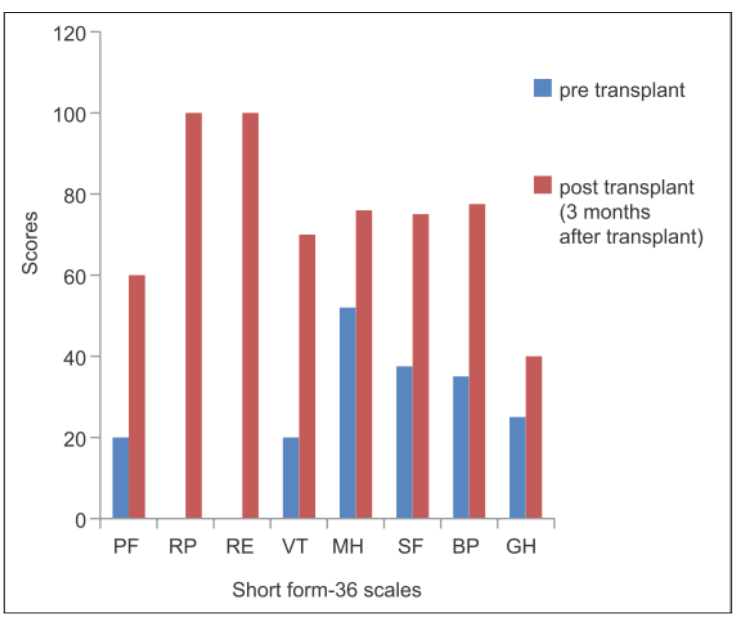

Figure 1: Comparison of quality of life by short form-36 questionnaire pre- and post-transplant. PF: physical functioning; RP: role limitation due to physical health; RE: role limitation due to emotional problem; VT: vitality; $\mathrm{MH}$ : mental health; SF: social function; BP: body pain; GH: general health 


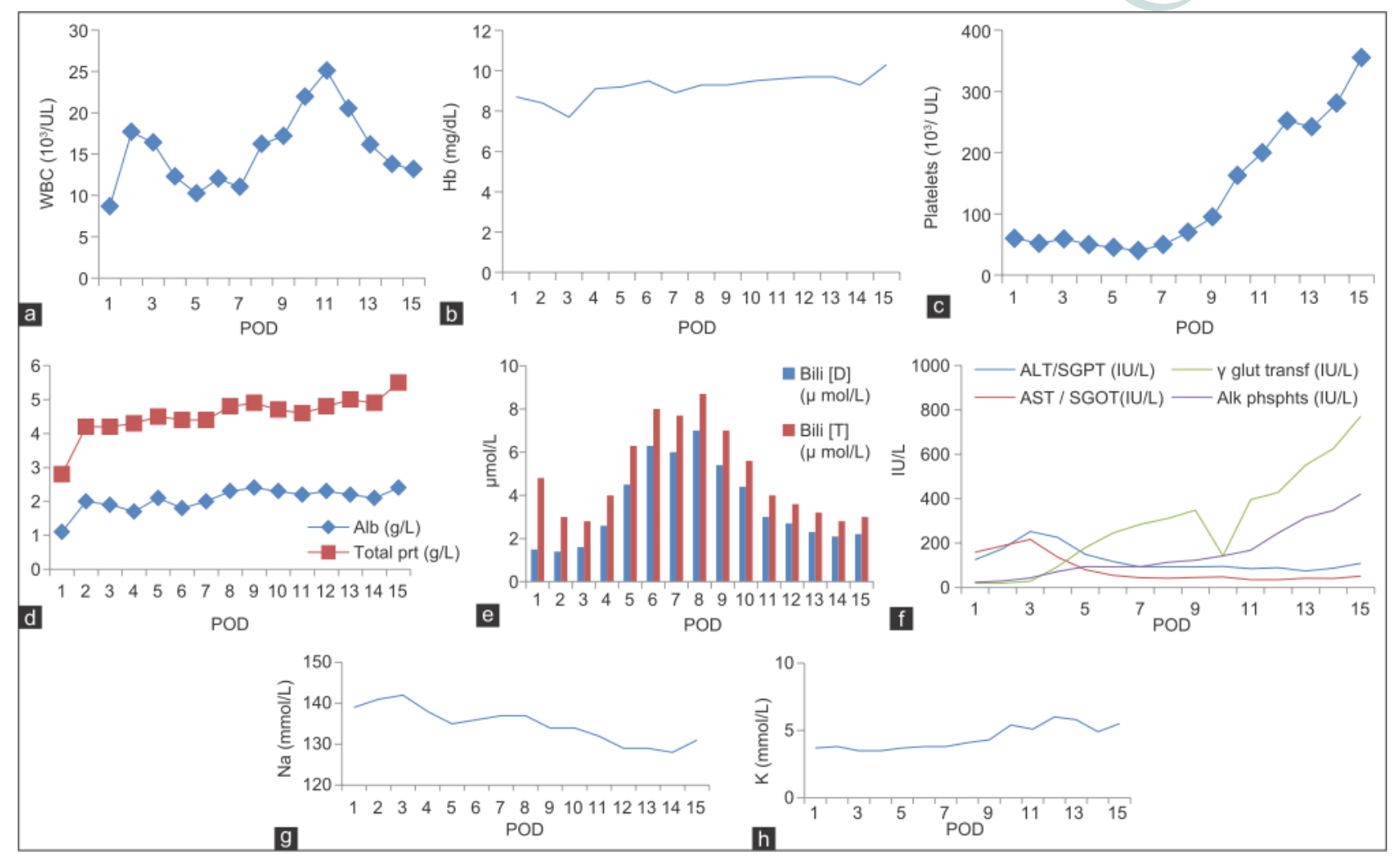

Figure 2: Each panel depicts acute post-operative patient profile of WBC (a), hemoglobin (b), platelets (c), albumin and total protein (d), bilirubin (D and T) (e), AST, ALT, $\gamma$ glutamyl transpeptidase and alkaline phosphates (f), sodium (g), and potassium (h), respectively. Hb: hemoglobin; WBC: white blood cell; Alb: albumin; Bili: bilirubin; AST: aspartate aminotransferase; ALT: alanine aminotransferase; POD: post-operation day

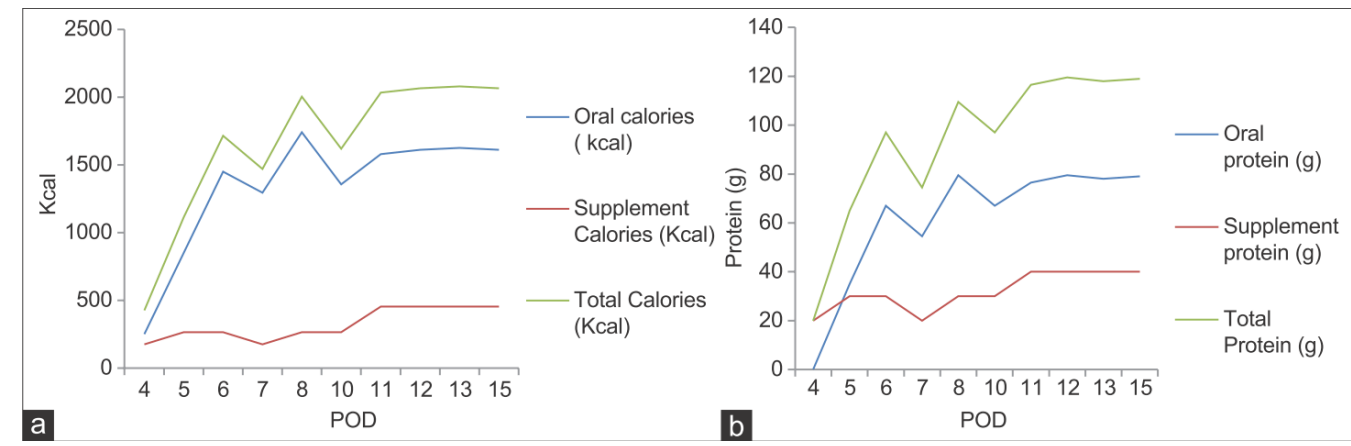

Figure 3: Energy (a) and protein (b) intake of the patient during the hospital stay after the transplant. POD: post-operation day

source of infection.

\section{Chronic post-transplant phase}

Gradual improvement in all the biochemical parameters was seen after 3 months of LT [Table 3]. The patient regularly visited the hepatologist after the surgery but never visited the dietician. The patient's intake was $1983 \mathrm{kcal}$ and $78.9 \mathrm{~g}$ protein from the oral diet without any nutritional supplement. The recommended intake amounts to 2,280 kcal and $76 \mathrm{~g}$ of protein. ${ }^{[4]}$ Hence, patient met $83.9 \%$ of calorie requirements.

The patient was not having any GI problem; he was able to perform daily routine functions. The SNAQ score was 16 which showed no significant risk of at least
5\% weight loss within 6 months. ${ }^{[11]} \mathrm{QOL}$ assessment depicted improvement of all the eight dimensions 3 months after LT [Figure 1]. ${ }^{[14]}$ The performance status assessment by ECOG improved from a score of 3 to 1 which indicated that the patient was restricted in physically strenuous activity but was ambulatory and able to carry out work of a light or sedentary nature. ${ }^{[13]}$ Nutrition status assessment is depicted in Table 4. Anthropometric examination through, MAMC ${ }^{[7]}$ showed similar results as in pre-transplant phase, which is mild malnutrition. Triceps measurement improved from severe malnutrition to normal range. ${ }^{[7]}$ SGA scores improved from moderate malnutrition to normal. ${ }^{[8]}$ Body composition analysis depicted higher levels of fat percentage and FFM after 3 months of LT. ${ }^{[10]}$ Hand grip 
Table 3: Patients' biochemical profile after discharge

\begin{tabular}{|c|c|c|c|c|c|c|c|c|c|c|c|c|c|}
\hline $\begin{array}{l}\text { Days after } \\
\text { discharge }\end{array}$ & $\begin{array}{c}\mathrm{Hb} \\
(\mathrm{mg} / \mathrm{dL})\end{array}$ & $\begin{array}{c}\text { WBC } \\
\left(10^{3} / \mathrm{UL}\right)\end{array}$ & $\begin{array}{l}\text { Platelets } \\
\left(10^{3} / \mathrm{UL}\right)\end{array}$ & $\begin{array}{c}\mathrm{Bil}(\mathrm{T}) \\
\text { (mg/dL) }\end{array}$ & $\begin{array}{c}\text { Bil (D) } \\
\text { (mg/dL) }\end{array}$ & $\begin{array}{c}\text { AST } \\
\text { (IU/L) }\end{array}$ & $\begin{array}{c}\text { ALT } \\
\text { (IU/L) }\end{array}$ & $\begin{array}{c}\text { Alkaline } \\
\text { phosphates }\end{array}$ & $\begin{array}{c}\gamma \text { glutamyl } \\
\text { transferase (IU/L }\end{array}$ & $\begin{array}{c}\text { Alb } \\
\text { (g/dL) }\end{array}$ & $\begin{array}{c}\mathrm{Na} \\
(\mathrm{mmol} / \mathrm{L})\end{array}$ & $\begin{array}{c}\mathrm{K} \\
(\mathrm{mmol} / \mathrm{L})\end{array}$ & $\begin{array}{c}\mathrm{Cr} \\
(\mathrm{mg})\end{array}$ \\
\hline$\overline{1}$ & 9.5 & 12.02 & 40 & 8 & 6.3 & 54 & 117 & 92 & 245 & 1.8 & 136 & 3.8 & 0.8 \\
\hline 2 & 8.9 & 11.02 & 50 & 7.7 & 6 & 44 & 92 & 94 & 284 & 2 & 137 & 3.8 & \\
\hline 3 & 9.3 & 16.2 & 70 & 8.7 & 7 & 41 & 92 & 113 & 311 & 2.3 & 137 & 4.1 & 0.8 \\
\hline 4 & 9.3 & 17.18 & 95 & 7 & 5.4 & 45 & 92 & 122 & 348 & 2.4 & 134 & 4.3 & 0.8 \\
\hline 5 & 9.5 & 21.93 & 163 & 5.6 & 4.4 & 47 & 95 & & 362 & 2.4 & 134 & 5.4 & 0.8 \\
\hline 6 & 9.6 & 25.6 & 200 & 4 & 3 & 34 & 84 & 167 & 396 & 2.2 & 132 & 5.1 & 0.9 \\
\hline 7 & 9.7 & 20.51 & 252 & 3.6 & 2.7 & 35 & 89 & 245 & 428 & 2.3 & 129 & 6 & 1 \\
\hline 8 & 9.6 & 16.13 & 242 & 3.2 & 2.3 & 41 & 74 & 314 & 552 & 2.2 & 129 & 5.8 & 1 \\
\hline 9 & 9.2 & 8.09 & 185 & 1.5 & 0.9 & 30 & 117 & 82 & 195 & 1.9 & 131 & 4.6 & 0.8 \\
\hline 10 & 10.3 & 10.17 & 355 & 3 & 2.2 & 51 & 109 & 421 & 772 & 2.4 & 131 & 5.5 & 0.9 \\
\hline 12 & 9 & 13.14 & 305 & 2.1 & 1.6 & 52 & 78 & 287 & 733 & 2.2 & 133 & 4.1 & 1 \\
\hline 15 & 9 & 13.19 & 300 & 2.3 & 2 & 105 & 196 & 294 & 737 & 2.3 & 137 & 3.3 & 0.9 \\
\hline 19 & 9.8 & 17.86 & 373 & 2 & 1.7 & 67 & 221 & 325 & 828 & 2.6 & 138 & 3.7 & 0.9 \\
\hline 26 & 11.20 & 15.48 & 301 & 1.0 & 0.8 & 57 & 119 & 213 & 623 & 2.50 & & & 1.0 \\
\hline 33 & 11.30 & 17.37 & 312 & 0.7 & 0.7 & 42 & 86 & 178 & 474 & 2.50 & & 4.0 & 0.8 \\
\hline 34 & 11.70 & 13.27 & 311 & 0.7 & 0.5 & 39 & 83 & 162 & 449 & 2.60 & & & \\
\hline 41 & 12.40 & 14.80 & 326 & 0.6 & & 44 & 91 & 169 & 382 & 2.90 & 135 & 5.3 & 0.9 \\
\hline 53 & 11.30 & 13.05 & 328 & 0.3 & 0.2 & 38 & 69 & & & & & & \\
\hline 54 & 12.20 & 13.22 & 308 & 0.5 & 0.4 & 55 & 102 & 160 & 283 & 2.70 & & & \\
\hline 72 & 10.90 & 22.63 & & 0.6 & 0.2 & 29 & 42 & 220 & & 4.90 & 146 & 4.2 & 1.3 \\
\hline 88 & & & & 0.4 & 0.3 & 23 & 32 & 116 & 107 & 3.10 & 140 & 4.8 & \\
\hline
\end{tabular}

$\mathrm{Hb}$ : haemoglobin; WBC: white blood cell; Alb: albumin; Bili: bilirubin; AST: aspartate aminotransferase; ALT: alanine aminotransferase; Cr: creatinine

Table 4: Comparison of nutritional status in pre-transplant and chronic post-transplant phase (3 months after LT)

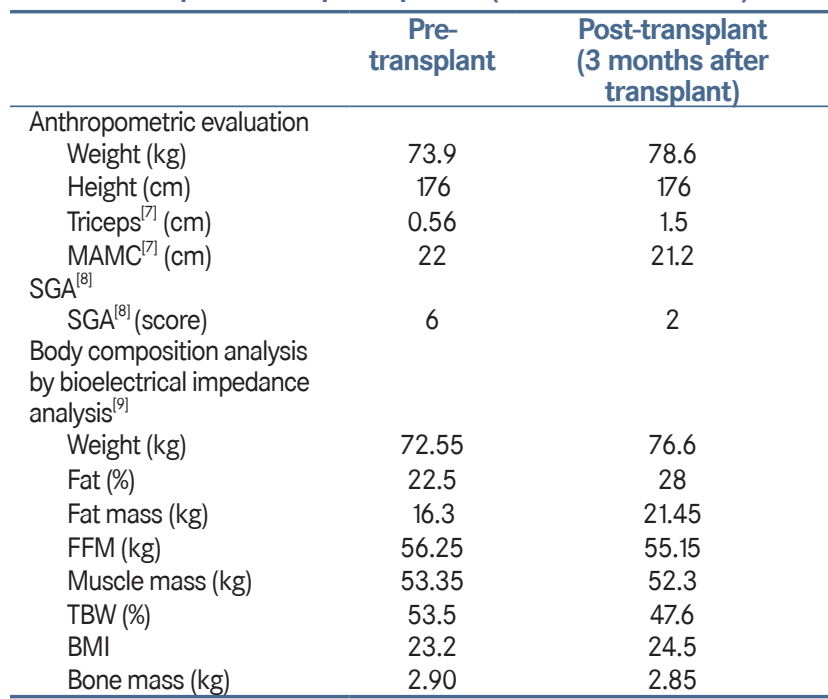

MAMC: mid-arm muscle circumference; SGA: subjective global assessment; FFM: fat-free mass; TBW: total body water; BMI: body mass index; LT: liver transplantation

strength (both hands) showed severe malnutrition similar to pre-transplant phase. ${ }^{[9]}$

\section{DISCUSSION}

A high incidence of malnutrition has been seen in LT recipients..$^{[5,14,15]}$ Accurate estimation of the nutritional status of patients with ESLD presents a major challenge due to fluid retention found in patients and the effect of liver function on protein synthesis. ${ }^{[16]}$ Malnutrition has also been associated with poor surgery outcome and increased morbidity and mortality. In India, LT is a relatively new area, and there is a lack of data about the general and nutritional profile of patients undergoing LT. It is essential to identify and correct nutritional deficiencies in LT recipients. Hence, this case report provides information on the day to day nutrition profile and the medical nutrition therapy of a LT recipient with the aim of improving outcomes.

A gradual improvement in the nutrition, biochemical, and functional parameters was seen after 3 months of transplant. Nutrition assessment by SGA, triceps, and body composition analysis showed better nutrition status 3 months after LT. During the acute post-transplant phase, continuous observation by medical and nutrition experts helped to fulfill nutritional needs through various feeding routes. However, the difference in calorie and protein intake in chronic post-transplant phase is due to lack of counseling from nutrition experts. Hence, proper nutrition monitoring is required during all phases of transplant to maintain the overall health of the patient.

\section{Acknowledgments}

Dr. A. S. Soin: Chief Hepatobiliary and Liver Transplant Surgeon and Chairman of Medanta Institute of Liver Transplantation and Regenerative Medicine, Medanta, The Medicity, Gurgaon, India, for permitting the author to collect information regarding liver transplant patients from their institute. 


\section{Financial support and sponsorship}

Nil.

\section{Conflicts of interest}

There are no conflicts of interest.

\section{REFERENCES}

1. O'Leary JG, Lepe R, Davis GL. Indications for liver transplantation. Gastroenterology 2008;134:1764-76.

2. Stephenson GR, Moretti EW, El-Moalem H, Clavien PA, TuttleNewhall JE. Malnutrition in liver transplant patients: preoperative subjective global assessment is predictive of outcome after liver transplantation. Transplantation 2001;72:666-70.

3. Lautz HU, Selberg O, Körber J, Bürger M, Müller MJ. Protein-calorie malnutrition in liver cirrhosis. Clin Investig 1992;70:478-86.

4. Plauth M, Cabré E, Riggio O, Assis-Camilo M, Pirlich M, Kondrup J; DGEM (German Society for Nutritional Medicine), Ferenci P, Holm E, Vom Dahl S, Müller MJ, Nolte W; ESPEN (European Society for Parenteral and Enteral Nutrition). ESPEN guidelines on Enteral Nutrition: Liver disease. Clin Nutr 2006;25:285-94.

5. Pugh RN, Murray-Lyon IM, Dawson JL, Pietroni MC, Williams R. Transection of the oesophagus for bleeding oesophageal varices. $\mathrm{Br} \mathrm{J}$ Surg 1973;60:646-9.

6. Wiesner R, Edwards E, Freeman R, Harper A, Kim R, Kamath P, Kremers W, Lake J, Howard T, Merion RM, Wolfe RA, Krom R; United Network for Organ Sharing Liver Disease Severity Score Committee. Model for end-stage liver disease (MELD) and allocation of donor livers. Gastroenterology 2003;124:91-6.

7. Jelliffe DB, Jelliffe EF, Zerfas A, Neumann CG. Community Nutritional Assessment with Special Reference to Less Technically Less Developed Countries. Oxford: Oxford University Press; 1989.

8. Detsky AS, McLaughlin JR, Baker JP, Johnston N, Whittaker S, Mendelson RA, Jeejeebhoy KN. What is subjective global assessment of nutritional status? JPEN J Parenter Enteral Nutr 1987;11:8-13.

9. TANITA. Multi-Frequency Body Composition Analyzer MC-180MA Instruction Manual. 2005. p. 1-61.

10. Wilson MM, Thomas DR, Rubenstein LZ, Chibnall JT, Anderson S, Baxi A, Diebold MR, Morley JE. Appetite assessment: simple appetite questionnaire predicts weight loss in community-dwelling adults and nursing home residents. Am J Clin Nutr 2005;82:1074-81.

11. Ewing JA. Detecting alcoholism. The CAGE questionnaire. JAMA 1984;252:1905-7.

12. Oken MM, Creech RH, Tormey DC, Horton J, Davis TE, McFadden ET, Carbone PP. Toxicity and response criteria of the Eastern Cooperative Oncology Group. Am J Clin Oncol 1982;5:649-55.

13. Ware JE Jr, Gandek B. Overview of the SF-36 Health Survey and the International Quality of Life Assessment (IQOLA) project. J Clin Epidemiol 1998;51:903-12.

14. Hasse JM. Nutritional implications of liver transplantation. Henry Ford Hosp Med J 1990;38:235-40.

15. Sanchez AJ, Aranda-Michel J. Nutrition for liver transplant patients. Liver Transpl 2006;12:1310-6.

16. Lochs H, Plauth M. Liver cirrhosis: rationale and modalities for nutritional support - the European Society of Parenteral and Enteral Nutrition consensus and beyond. Curr Opin Clin Nutr Metab Care 1999;2:345-9. 